\title{
Therapeutic difficulties in a patient with a generalized form of annular granuloma
}

\section{Trudności terapeutyczne u pacjenta z uogólnioną postacią ziarniniaka obrączkowatego}

Jagoda Stroynowska-Kosik, Ewelina Biało-Wójcicka

Adult Dermatology Ward, Tertiary Hospital of Miedzylesie, Warsaw, Poland

Oddział Dermatologii Dorosłych, Międzyleski Szpital Specjalistyczny, Warszawa, Polska

Dermatol Rev/Przegl Dermatol 2021, 108, 320-324

DOI: https://doi.org// 0.5 | |4/dr.2021. I 10733

Annular granuloma (Lat. granuloma annulare - GA) is a mild chronic inflammatory dermatosis, classified as a granulomatous skin disease. It is estimated that in the European population, its incidence is $0.1-0.4 \%$ [1]. The disease occurs mainly in young adults and children. However, it can appear at any age [1, 2]. Women suffer twice as often, especially in the $5^{\text {th }}-6^{\text {th }}$ decade of life [3]. Etiology of the disease has not been fully understood yet. The prevailing view today is that a delayed type immune response plays a key role in the pathogenesis of GA. Local damage to the dermis is believed to activate CD4+ T lymphocytes, secreting pro-inflammatory factors, e.g., interferon- $\gamma$ (INF- $\gamma$ ), interleukin-2 (IL-2), tumor necrosis factor (TNF), which stimulate macrophages to produce extracellular matrix metalloproteases, which in turn results in the degradation of collagen fibers and the formation of granulomas visible in the histopathological picture $[4,5]$.

Typical clinical manifestation of GA involves hard, slightly raised lumps and nodules, with a smooth surface, flesh-colored or pale red in color, with a tendency to form ring-shaped foci that widen peripherally. Skin lesions are most often located on dorsal surfaces of hands and feet, but they can also occur in other locations. Usually they are not accompanied by subjective symptoms. However, itching of varying intensity may be present.

There are few publications in the dermatological literature on the methods of treating GA. Most of them are case studies. The choice of the appropriate therapy depends primarily on the clinical form of GA.

The most common type is the localized granuloma annulare (LGA), which occurs in about $75 \%$ of pa-
Ziarniniak obrączkowaty (granuloma annulare - GA) to łagodna przewlekła dermatoza zapalna, zaliczana do ziarniniakowych chorób skóry. Szacuje się, że w populacji europejskiej częstość jej występowania wynosi 0,1-0,4\% [1]. Choroba występuje głównie u młodych dorosłych i dzieci. Może jednak pojawić się w każdym wieku [1, 2]. Dwukrotnie częściej chorują kobiety, zwłaszcza w 5.-6. dekadzie życia [3]. Etiologia schorzenia nie została jeszcze dokładnie poznana. Obecnie przeważa pogląd, że kluczową rolę w patogenezie GA ma odpowiedź immunologiczna typu opóźnionego. Uważa się, że miejscowe uszkodzenie skóry właściwej aktywuje limfocyty T CD4+, wydzielające czynniki prozapalne, takie jak interferon $\gamma(\mathrm{INF}-\gamma)$, interleukina 2 (IL-2), czynnik martwicy nowotworu (TNF), które pobudzają makrofagi do produkcji metaloproteaz macierzy pozakomórkowej, co skutkuje degradacją włókien kolagenowych i tworzeniem się widocznych w obrazie histopatologicznym ziarniniaków [4, 5].

Typowy obraz kliniczny GA to twarde, nieco wyniosłe grudki i guzki, o gładkiej powierzchni, barwy cielistej lub bladoczerwonej, $\mathrm{z}$ tendencją do tworzenia się obrączkowatych ognisk, poszerzających się obwodowo. Zmiany skórne najczęściej umiejscowione są w obrębie grzbietowych powierzchni rąk i stóp, ale mogą występować również w innych lokalizacjach. Zazwyczaj nie towarzyszą im dolegliwości subiektywne. Możliwa jest jednak obecność różnie nasilonego świądu.

$\mathrm{W}$ literaturze dermatologicznej istnieje niewiele publikacji dotyczących metod leczenia GA. Większość z nich to prace pojedynczych przypadków klinicznych. Wybór odpowiedniej terapii zależy przede wszystkim od postaci klinicznej GA.

Najczęstszą odmianą jest postać ograniczona (localized granuloma annulare - LGA), która występuje u około 
tients, more often in children and young adults [1]. In most LGA patients, skin lesions resolve spontaneously, usually within 2 years [1], therefore in some cases, especially in pediatric patients, a wait-and-see attitude may be considered [6]. In other cases, topical treatment with glucocorticosteroids, $0.1 \%$ tacrolimus or 5\% imiquimod [7], and according to recent reports also $2 \%$ tofacitinib proves effective [8]. Another LGA therapeutic method involves intralesional injections of glucocorticosteroids or INF- $\gamma$ [9]. Good effects of cryotherapy [10], photodynamic therapy [11] and laser treatments [12] have also been reported.

The second most common type is generalized granuloma annulare (GGA), also referred to as disseminated granuloma annulare (DGA). It is found in approximately $15 \%$ of GA patients, mainly in adults [13]. Skin lesions in GGA are more often accompanied by varying degrees of itching. Moreover, it is characterized by a more chronic course and a worse response to treatment compared to the localized form. In addition, in patients with GGA the disease more likely coexists with systemic diseases, which may further complicate selection of an effective therapeutic method. The most common diseases coexisting with GA include: diabetes mellitus, dyslipidemia, thyroid disease, HBV, HCV and HIV infections, and malignant neoplasms (mainly lymphomas) [14]. Local therapy for GGA is seldom sufficient, therefore systemic treatment is indicated.

We present difficulties in selecting an effective therapeutic method in a 58-year-old patient with GGA. Skin lesions in the form of itchy erythematous, annular papules, showing a tendency to cluster in a reticular pattern, located around the trunk and limbs, appeared about a year before admission to the Dermatology Ward, without any detectable triggering factor (figs. 1, 2). Previous outpatient treatment has generally used antihistamines and topical anti-inflammatory preparations - with no satisfactory improvement. In addition, the patient had a history of hypertension, type 2 diabetes, hypothyroidism and lipid metabolism disorders. No significant deviations were found in the laboratory and imaging diagnostics performed during hospitalization (X-ray of the chest and ultrasound of the abdomen). In the microscopic image of a biopsy specimen from the follicular lesion, foci of collagen necrosis with peripherally arranged epithelial cells of the granulomatous nature were visible. Based on the clinical presentation and result of the histopathological examination, the diagnosis of GGA was made. According to literature data, the basic therapeutic method in the case of GGA involves the use of various forms of phototherapy, including NB-UVB (311 nm), UVA1 and PUVA [15]. Therefore, in the presented patient, irradiation with NB-UVB was started, which the patient continued further on an outpatient basis. After the treatment, only
75\% pacjentów, częściej u dzieci i młodych dorosłych [1]. U większości chorych z LGA zmiany skórne ustępują samoistnie, zazwyczaj w czasie 2 lat [1], dlatego też w niektórych przypadkach, zwłaszcza u pacjentów pediatrycznych, można rozważyć postawę wyczekującą [6]. W pozostałych przypadkach skuteczne jest leczenie miejscowe preparatami glikokortykosteroidowymi, 0,1\% takrolimusu lub 5\% imikwimodu [7], a według ostatnich doniesień także $2 \%$ tofacytynibu [8]. Kolejną metodą terapeutyczną LGA są doogniskowe iniekcje glikokortykosteroidów lub INF- $\gamma$ [9]. Stwierdzono również dobre efekty krioterapii [10], terapii fotodynamicznej [11] oraz zabiegów laserowych [12].

Drugą co do częstości występowania jest odmiana uogólniona ziarniniaka obrączkowatego (generalized granuloma annulare - GGA), określana też jako rozsiana (disseminated granuloma annulare - DGA). Stwierdza się ją u około 15\% pacjentów z GA, głównie u osób dorosłych [13]. Zmianom skórnym w GGA częściej towarzyszy różnie nasilony świąd. Charakteryzuje się ona bardziej przewlekłym przebiegiem i gorszą odpowiedzią na leczenie $\mathrm{w}$ porównaniu $\mathrm{z}$ postacią zlokalizowaną. Dodatkowo u pacjentów z GGA częściej stwierdza się współwystępowanie chorób ogólnoustrojowych, co dodatkowo może utrudniać wybór skutecznej metody terapeutycznej. Do chorób najczęściej współistniejących z GA zalicza się: cukrzycę, dyslipidemię, choroby tarczycy, zakażenia HBV, HCV i HIV oraz nowotwory złośliwe (głównie chłoniaki) [14]. Terapia miejscowa w przypadku GGA rzadko bywa wystarczająca, dlatego wskazane jest leczenie ogólnoustrojowe.

Przedstawiamy trudności w wyborze skutecznej metody terapeutycznej u 58-letniego pacjenta $\mathrm{z}$ postacią GGA. Zmiany skórne w postaci swędzących rumieniowych grudek o układzie obrączkowatym, wykazujących tendencję do skupiania się w siateczkowaty wzór, zlokalizowanych w obrębie tułowia i kończyn pojawiły się około roku przed przyjęciem na oddział dermatologii, bez uchwytnego czynnika wyzwalającego (ryc. 1, 2). W leczeniu ambulatoryjnym stosowano ogólnie leki przeciwhistaminowe i miejscowe preparaty przeciwzapalne - bez zadowalającej poprawy. Poza tym chory $\mathrm{w}$ wywiadzie podawał nadciśnienie tętnicze, cukrzycę typu 2, niedoczynność tarczycy i zaburzenia gospodarki lipidowej. W wykonanej w trakcie hospitalizacji diagnostyce laboratoryjnej i obrazowej (RTG klatki piersiowej i USG jamy brzusznej) nie stwierdzono istotnych odchyleń od normy. W obrazie histopatologicznym wycinka ze zmiany grudkowej uwidoczniono ogniska martwicy kolagenu z obwodowo ułożonymi komórkami nabłonkowatymi o charakterze zapalenia ziarniniakowego. Na podstawie obrazu klinicznego i wyniku badania histopatologicznego ustalono rozpoznanie postaci GGA. Według danych z piśmiennictwa podstawową metodą terapeutyczną w przypadku GGA są różne formy fototerapii, w tym NB-UVB (311 nm), UVA1 oraz PUVA [15]. W związku z tym u przedstawionego pacjenta roz- 


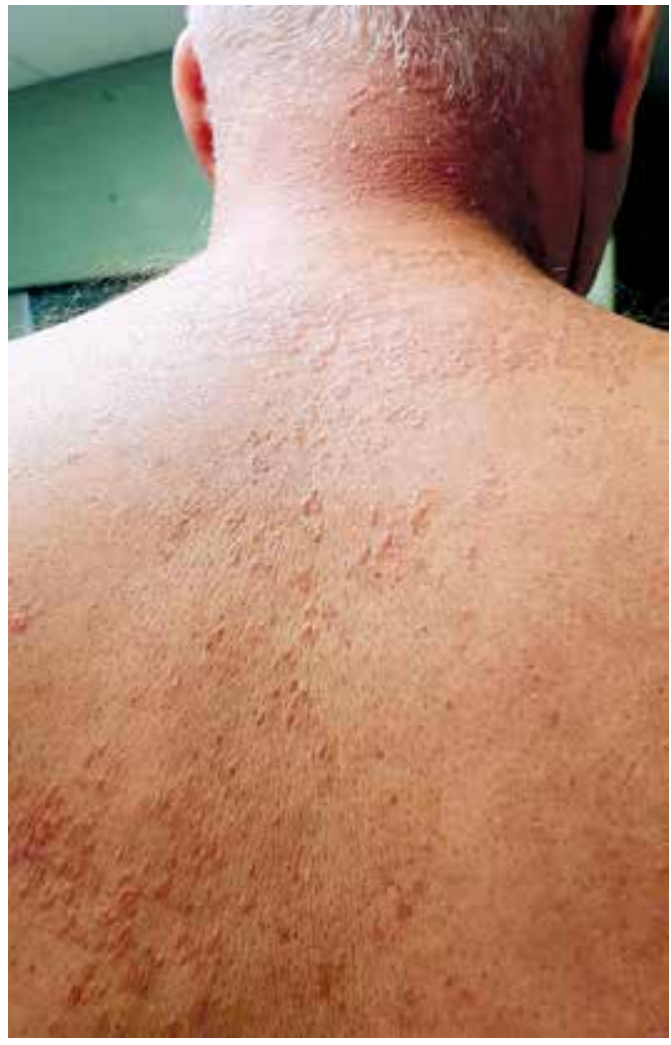

Figure I. The papular skin lesions with a characteristic ring pattern on the back

Rycina I. Zmiany skórne grudkowe o charakterystycznym układzie obrączkowatym na plecach

a slight flattening of skin lesions was observed, and the skin itching persisted. Therefore, a switch to PUVA therapy was planned. This method seems to be particularly useful in the treatment of GGA not only due to the immunosuppressive effect on CD4 T cells, and consequently limiting the destruction of the extracellular matrix, but also due to the direct cytotoxic effect on histiocytes, fibroblasts and other inflammatory cells. However, caution should be exercised due to the possibility of provoking new skin lesions or exacerbation of the present ones as a result of exposure to light [16]. In order to exclude any contraindications to this therapeutic method, the patient was consulted ophthalmologically - inflammatory changes in the cornea, diabetic retinopathy, and the initial stage of cataract were diagnosed, and glaucoma was suspected. Due to ophthalmic reasons, PUVA-therapy was abandoned [17]. Moreover, antimalarial treatment was abandoned due to the negative influence of these drugs on the retina (the so-called chloroquine retinopathy) [18]. According to the literature data, chloroquine and hydroxychloroquine are effective in the treatment of GGA. They exhibit anti-inflammatory and immunosuppressive effects. Probably the efficacy in the treatment of GA results from inhibition of TNF production, and consequently from limited degradation of the extracellular matrix. Moreover, antimalarial drugs have lipid-lower-

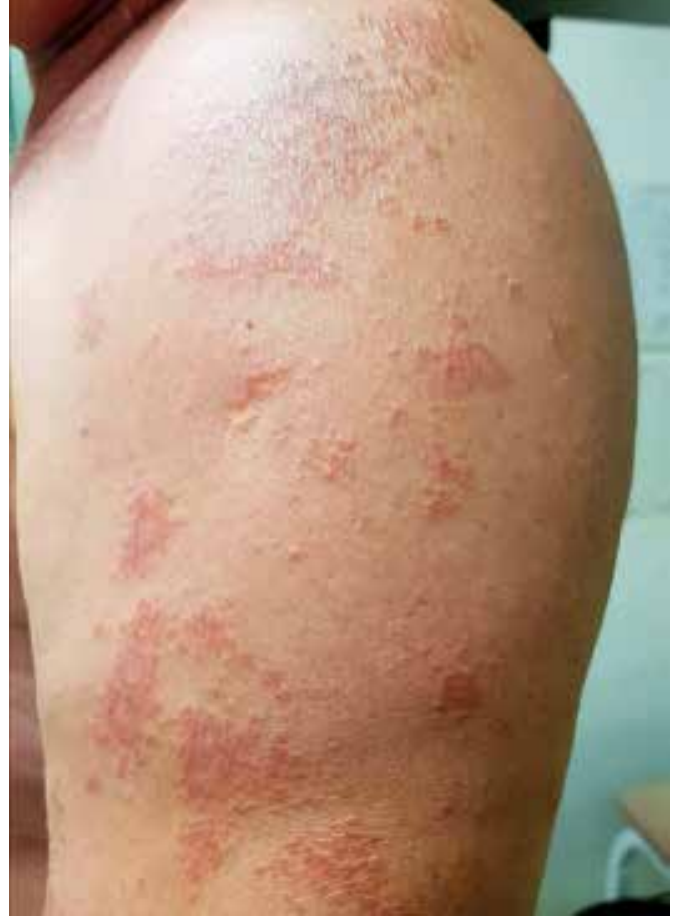

Figure 2. The papular skin lesions with a tendency to focus on the arm

Rycina 2. Zmiany skórne grudkowe z tendencją do skupiania się na ramieniu

poczęto naświetlania NB-UVB, które mężczyzna kontynuował w trybie ambulatoryjnym. Po zastosowanym leczeniu obserwowano tylko nieznaczne spłaszczenie zmian skórnych, nadal utrzymywał się świąd skóry. Zaplanowano zmianę terapii na PUVA. Metoda ta wydaje się szczególnie przydatna w leczeniu GGA nie tylko z uwagi na immunosupresyjny wpływ na limfocyty $T$ CD4, a w konsekwencji ograniczenie destrukcji macierzy pozakomórkowej, lecz także na bezpośredni cytotoksyczny wpływ na histiocyty, fibroblasty i inne komórki nacieku zapalnego. Należy jednak zachować ostrożność ze względu na możliwość sprowokowania nowych zmian skórnych lub zaostrzenia obecnie występujących pod wpływem ekspozycji na światło [16]. W celu wykluczenia ewentualnych przeciwwskazań do powyższej metody terapeutycznej pacjenta skonsultowano okulistycznie - rozpoznano zmiany zapalne w obrębie rogówki, retinopatię cukrzycową, początkowe stadium zaćmy oraz wysunięto podejrzenie jaskry. Z przyczyn okulistycznych odstąpiono od włączenia PUVA-terapii [17]. Poza tym zrezygnowano z terapii lekami przeciwmalarycznymi z powodu negatywnego wpływu tych preparatów na siatkówkę (tzw. retinopatia chlorochinowa) [18]. Według danych z piśmiennictwa chlorochina i hydroksychlorochina są skuteczne w leczeniu GGA. Mają one działanie przeciwzapalne i immunosupresyjne. Prawdopodobnie skuteczność w terapii GA wynika z hamowania produkcji TNF, a także ograniczania degradacji macierzy zewnątrzkomórkowej. Poza tym leki antymalaryczne 
ing and hypoglycemic properties, which may provide additional benefits in patients with diabetes and lipid metabolism disorders [18, 19]. Systemic corticosteroid therapy could not be initiated in the described patient due to type 2 diabetes, diabetic retinopathy and newly diagnosed cataract. In the treatment of GA, usually high doses are required, which at the same time increases the risk of many adverse effects [20]. Finally, in the presented patient, a decision was made to include dapsone in the initial dose of $50 \mathrm{mg} /$ day. Then, with the correct level of methemoglobin, the dose was increased to $100 \mathrm{mg} /$ day, observing improvement of the patient's clinical condition. Dapsone is a drug belonging to the group of sulfones, characterized by the simplest structure among sulfone drugs. Its action is of a dual nature: antibacterial or antiparasitic and antiinflammatory. In dermatology, its anti-inflammatory effect is primarily used, which consists in inhibition of chemotaxis of polynuclear leukocytes and activation of the complement via an alternative route [21, 22]. Dapsone is the drug of first choice in the treatment of, among others: herpetiform dermatitis, IgA pemphigus, linear IgA bullous dermatosis, subcorneal pustular dermatosis as well as hemorrhagic and long-lasting erythema. It is also a useful therapeutic option in many other inflammatory dermatoses, including generalized form of annular granuloma, which is confirmed by the clinical case described here. Contraindications to the use of dapsone involve hypersensitivity to the drug and severe anemia. An important adverse effect of using the drug is methemoglobinemia. Therefore, the patient's blood levels of methemoglobin should be monitored regularly during the treatment with dapsone. It is also important to assess glucose-6-phosphate dehydrogenase before starting the treatment, because its deficiency may exacerbate the symptoms of methemoglobinemia [22].

There are reports in the dermatological literature on effectiveness of many other drugs in the treatment of GGA, including: local and systemic retinoids, sulfasalazine [23], fumaric acid esters [24], TNF inhibitors $[20,25]$, methotrexate, cyclosporine, pentoxifylline, hydroxyurea and tetracyclines [20]. According to recent scientific publications, a promising therapeutic option is also tofacitinib - a drug from the group of JAK tyrosine kinase inhibitors [26].

The GGA may pose therapeutic difficulties, which is confirmed by the clinical case described above. It seems that a better understanding of etiopathogenesis, exacerbating factors and of relationships with systemic diseases would allow for a more effective treatment of this type of GA.

\section{CONFLICT OF INTEREST}

The authors declare no conflict of interest. działają hipolipemizująco i hipoglikemizująco, co może dać dodatkową korzyść u pacjentów z cukrzycą i zaburzeniami gospodarki lipidowej $[18,19]$. U opisywanego pacjenta nie można było rozpocząć ogólnoustrojowej glikokortykosteroidoterapii z powodu cukrzycy typu 2, retinopatii cukrzycowej i nowo rozpoznanej zaćmy. W leczeniu GA wymagane jest stosowanie zwykle wysokich dawek, co jednocześnie zwiększa ryzyko wystąpienia wielu działań niepożądanych [20]. Ostatecznie u przedstawionego pacjenta zdecydowano się na włączenie dapsonu w początkowej dawce $50 \mathrm{mg} /$ dobę. Następnie przy prawidłowym stężeniu methemoglobiny dawkę zwiększono do $100 \mathrm{mg} /$ dobę, obserwując poprawę stanu klinicznego chorego. Dapson jest lekiem zaliczanym do grupy sulfonów, charakteryzującym się najprostszą budową strukturalną wśród leków sulfonowych. Ma on podwójne działanie - przeciwbakteryjne lub przeciwpasożytnicze oraz przeciwzapalne. $W$ dermatologii wykorzystuje się przede wszystkim jego działanie przeciwzapalne, które polega na hamowaniu chemotaksji leukocytów wielojądrzastych i aktywacji dopełniacza droga alternatywną [21, 22]. Dapson jest lekiem pierwszego wyboru w terapii m.in.: opryszczkowatego zapalenia skóry, pęcherzycy IgA, linijnej IgA pęcherzowej dermatozy, podrogowej krostkowej dermatozy oraz rumienia wyniosłego i długotrwałego. Stanowi też przydatną opcję terapeutyczną w wielu innych dermatozach zapalnych, w tym w uogólnionej postaci ziarniniaka obrączkowatego, co potwierdza opisany powyżej przypadek kliniczny. Przeciwwskazaniami do stosowania dapsonu są nadwrażliwość na lek i ciężka niedokrwistość. Istotnym objawem niepożądanym stosowania tego preparatu jest methemoglobinemia. Dlatego też w trakcie terapii dapsonem należy regularnie monitorować poziom methemoglobiny we krwi pacjenta. Ważna jest także przed rozpoczęciem leczenia ocena dehydrogenazy glukozo-6-fosforanowej, ponieważ jej niedobór może nasilać objawy methemoglobinemii [22].

W literaturze dermatologicznej istnieją doniesienia o skuteczności w leczeniu GGA wielu innych leków, takich jak retinoidy miejscowe i ogólne, sulfasalazyna [23], estry kwasu fumarowego [24], inhibitory TNF [20, 25], metotreksat, cyklosporyna, pentoksyfilina, hydroksymocznik oraz tetracykliny [20]. Według ostatnich publikacji obiecującą opcją terapeutyczną jest także tofacytynib - lek z grupy inhibitorów kinazy tyrozynowej JAK [26].

Postać GGA może stwarzać trudności terapeutyczne, co potwierdza opisany powyżej przypadek kliniczny. Wydaje się, że lepsze poznanie etiopatogenezy, czynników zaostrzających i powiązania z chorobami ogólnoustrojowymi pozwoliłoby na skuteczniejsze leczenie tej odmiany GA.

\section{KONFLIKT INTERESÓW}

Autorzy nie zgłaszają konfliktu interesów. 


\section{References}

\section{Piśmiennictwo}

1. Schmieder S.J., Harper C.D., Schmieder G.J.: Granuloma annulare. In: StatPearls [Internet]. Treasure Island (FL): StatPearls Publishing 2021. Available from: https://www.ncbi.nlm.nih.gov/books/NBK459377/ [Updated 2021 Jan 5].

2. Reisenauer A., White K., Korcheva V., White C.R.: Non-infectious granulomas. [In:] Dermatology. J.L. Bolognia, J.L. Jorizzo, J.V. Schaffer (eds). Elsevier, Amsterdam, 2012, 1557-1568.

3. Burns D.A. Necrobiotic disorders. [In:] Rook's Texbook of Dermatology. D.A. Burns, S.M. Breathnach, N. Cox, C. Griffiths (eds.), Willey-Blacwell, Oxford, 2010, 60.1-60.12.

4. Fayyazi A., Schweyer S., Eichmeyer B., Herms J., Hemmerlein B., Radzun H.J., et al.: Expression of IFN-ү, coexpression of TNF- $\alpha$ and matrix metalloproteinases and apoptosis of T lymphocytes and macrophages in granuloma annulare. Arch Dermatol Res 2000, 292, 384-390.

5. Mempel M., Musette P., Flageul B., Schnopp C., Remling R., Gachelin G., et al.: T-cell receptor repertoire and cytokine pattern in granuloma annulare: defining particular type of cutaneous granulomatous inflammation. J Invest Dermatol 2002, 118, 957-966.

6. Patrizi A., Gurioli C., Neri I.: Childhood granuloma annulare: a review. G Ital Dermatol Venereol 2014, 149, 663-674.

7. Patrizi A., Neri I.: Granuloma annulare. [In:] Harper's Textbook of Pediatric Dermatology. P. Hoeger, V. Kinsler, A. Yan, J. Harper, A. Oranje, C. Bodemer, et al.: Wiley, Blackwell 2019.

8. Damsky W., King B.A.: Treatment of granuloma annulare with tofacitinib 2\% ointment. JAAD Case Rep 2019, 6, 69-71.

9. Weiss J.M., Muchenberger S., Schopf E., Simon J.C.: Treatment of granuloma annulare by local injections with low-dose recombinant human interferon gamma. J Am Acad Dermatol 1998, 39, 117-119.

10. Blume-Peytavi U., Zouboullis C.C., Jacobi H., Scholz A., Bisson S., Orfanos C.E.: Successful outcome of cryosurgery in patients with granuloma annulare. Br J Dermatol 1994, 130, 494-497.

11. Weisenseel P., Kuznetsov A., Molin S., Ruzicka T., Berking C., Prinz J.C.: Photodynamic therapy for granuloma annulare: more than a shot in the dark. Dermatology 2008, 217, 329-332.

12. Verne S.H., Kennedy J., Falto-Aizpurua L.A., Griffith R.D., Nouri K.: Laser treatment of granuloma annulare: a review. Int J Dermatol 2016, 55, 376-381.

13. Ehret M., Lenormand C., Scrivener J.N., Gusdorf L., Lipsker D., Cribier B.: Granulome annulaire généralisé: étude anatomoclinique [Generalized granuloma annulare: A clinicopathological study]. Ann Dermatol Venereol 2020, 147, 271-278.

14. Piette Evan W., Rosenbach M.: Granuloma annulare: pathogenesis, disease associations and triggers and therapeutic options. J Am Acad Dermatol 2016, 75, 467-479.

15. Cunningham L., Kirby B., Lally A., Collins P.: The efficacy of PUVA and narrowband UVB phototherapy in the management of generalised granuloma annulare. J Dermatolog Treat 2016, 27, 136-139.

16. Güneş P., Göktay F., Mansur A.T., Köker F., Erfan G.: Collagen-elastic tissue changes and vascular involvement in granuloma annulare: a review of 35 cases. J Cutan Pathol 2009, 36, 838-844.

17. Placek W., Kaszuba A., Lesiak A., Maj J., Narbutt J., Osmola-Mańkowska A., et al.: Phototherapy and photochemotherapy in dermatology. Recommendations of the Polish Dermatological Society. Dermatol Rev 2019, 106, 237-256.

18. Fernandez A.P.: Updated recommendations on the use of hydroxychloroquine in dermatologic practice. J Am Acad Dermatol 2017, 76, 1176-1182.

19. Grewal S.K., Rubin C., Rosenbach M.: Antimalarial therapy for granuloma annulare. Results of a retrospective analysis. J Am Acad Dermatol 2017, 76, 765-767.

20. Lukacs J., Schliemann S., Elsner P.: Treatment of generalized granuloma annulare - a systemic review. J Eur Acad Dermatol Venerol 2015, 29, 1467-1480.

21. Martin-Saez E., Fernandez-Guarino M., Carrillo-Gijon R., Munoz-Zato E., Jaen-Olasolo P.: Efficacy of dapsone in disseminated granuloma annulare: a case report and review of the literature. Actas Dermosifiliogr 2008, 99, 64-68.

22. Żychowska M., Batycka-Baran A., Szepietowski J., Baran W.: Dapson - mechanizm działania, bezpieczeństwo stosowania oraz rola w leczeniu pemfigoidu pęcherzowego w świetle najnowszych wytycznych. Dermatol Rev 2016, 103, 176-184.

23. Yang Y.W., Lehrer M.D., Mangold A.R., Yiannias J.A., Nelson S.A., Pittelkow M.R.: Treatment of granuloma annulare and related granulomatous diseases with sulphasalazine: a series of 16 cases J Eur Acad Dermatol Venereol 2021, 35, 211-215.

24. Weber H.O., Borelli C., Rocken M., Schaller M.: Treatment of disseminated granuloma annulare with low-dose fumaric acid. Acta Derm Venerol 2009, 89, 295-298.

25. Murdaca G., Colombo B.M., Barabino G., Caiti M., Cagnati P., Puppo F.: Anti-tumor necrosis factor-alpha treatment with infliximab for disseminated granuloma annulare. Am J Clin Dermatol 2010, 11, 437-439.

26. Wang A., Singh K., Ibrahim W., King B., Damsky W.: The promise of JAK inhibitors for treatment of sarcoidosis and other inflammatory disorders with macrophage activation: a review of the literature. Yale J Biol Med 2020, 93, 187-195.

Received: 21.09 .2020

Accepted: 24.03 .2021

Otrzymano: $21.09 .2020 \mathrm{r}$.

Zaakceptowano: 24.03 .2021

How to cite this article

Stroynowska-Kosik J., Biało-Wójcicka E.: Therapeutic difficulties in a patient with a generalized form of annular granuloma. Dermatol Rev/Przegl Dermatol 2021, 108, 320-324. DOI: https://doi.org/10.5114/dr.2021.110733. 